\title{
Egg quality in different lines of New Hampshire and Giriraja chicken
}

\author{
N Baskota ${ }^{1}$, M Sharma ${ }^{2}$, N Bhattrai ${ }^{2}$, D Neupane ${ }^{1}$, RK Yadav $^{3}$ and S Upreti ${ }^{1}$
}

${ }^{1}$ Nepal Agricultural Research Council, Lalithpur, Kathmundu, Nepal; ${ }^{2}$ Professor, Agriculture and Forestry University, Rampur, Chitwan, Nepal; ${ }^{3}$ Research Director, Universal Animal Breeding Private Ltd. Siraha, Nepal

\begin{abstract}
This study was undertaken to evaluate the egg quality parameters of New Hampshire and Giriraja by maintaining four different flocks (lines) of New Hampshire viz. NH-Khajura, NH-Parwanipur, $\mathrm{NH}-$ Khumaltar and NH-Pokhara and three different flocks (lines) of Giriraja viz. GR-Pakhribas, GR-Khumaltar and GR-Tarhara. The 40-60 weeks of hatchability, fertility, external and internal egg quality parameters were studied and recorded. A total of 200 birds ( 40 weeks of age) of each New Hampshire and Giriraja from each line were maintained on deep litter system. Results from this study indicated the significant effect of genotype and respective lines on fertility and hatchability of eggs. Significant $(P<0.05)$ variation in fertility and no significant variation in hatchability for genotypes were found. However, in terms of fertility and hatchability, there were significant variations in different lines. In case of egg weight: no significant $(P<0.01)$ variation was obtained for genotype but lines comparison showed significant variation. Other external egg quality parameters like egg length, egg diameter, shape index, shell thickness were examined for evaluating the genotype and line effect. In all these external egg quality parameters, there were significant $(P<0.01)$ effect of both genotype and lines of birds. For internal egg qualities, yolk weight $(\mathrm{g})$, yolk index, albumen weight and albumen index were checked. Genotype had no significant $(P<0.01)$ effect but lines had significant $(P<0.01)$ effect on yolk weight. In case of yolk index, both genotype and lines of bird had no significant effect. For albumen weight and albumen index, genotype of birds had no significant $(P<0.01)$ effect but lines of bird had significant $(P<0.01)$ effect on both parameters. The study showed that the egg quality parameters of $\mathrm{NH}$ (Khajura) were better than that of GR. Among different lines New Hampshire (Khajura) showed better performance in terms of egg quality parameter.
\end{abstract}

Keywords: egg quality, New Hampshire, Giriraja, genotype, line, chicken

Bangladesh Animal Husbandry Association. All rights reserved.

Bang. J. Anim. Sci. 2020. 49 (2):108-118

\section{Introduction}

Among the livestock, poultry are indispensable and important part of the agriculture enterprise which has become important choice for many Nepalese, especially in the rural areas. The total worth value from poultry business in 2015 was 33.7 billion out of which 20.7 billion was occupied by meat and 9.1 billion from eggs respectively (CBS, 2015). In spite of the rural poultry framing being of small scale, it contributes $4.0 \%$ of the Agricultural GDP with an output of 10 billion rupees each year (FAO, 2014). According to Parajuli et al. (1998), 46 percent of the total bird population is of indigenous or local poultry scattered throughout the country, mostly in rural areas and the remaining 54 percent of the poultry population are reared by organized commercial poultry farms confined mostly to large peri-urban areas. There is a growing awareness of the nutritive value of poultry meat among the people. Therefore, poultry farming has been an important enterprise in both rural and urban areas of the country (Bhurtel and Shah, 2000). Demand for the chicken is increasing because of its low price and health importance. Nowadays commercialization of livestock industry particularly in Poultry marketing is an increasing trend. The formulated Agriculture Development strategy, 2015 encourages the farmer's and the government towards the line of self-sufficient in terms of egg and meat production. However, there are many constraints to be addressed. For example, restricted use of the available genetic resources, encroachment by crop production, severely increasing inbreeding trend, shortage of labor etc. have negatively affected population of poultry in the hills and different regions of Nepal. Therefore, it has become important to identify the appropriate breed and genotypes of poultry that could be further used to improve its productivity using locally available feed resources and with the available low inputs. Therefore selection of suitable breed of available poultry birds by strengthening the management system, 
Baskota et al. (2020) Bang. J. Anim. Sci. 49 (2):108-118

characterization, better understanding at phenotypic and genotypic level are the immense needs. Therefore the study has been undertaken to explore the egg production traits of different lines of poultry breeds available at the government resource farms.

\section{Materials and Methods}

\section{Experimental site}

The experiment was conducted in the Swine and Avian research Program, Lalitpur, Nepal.

\section{Management of birds}

A total of 200 birds ( 40 weeks to 60 weeks of age) of each New Hampshire and Giriraja from each line were managed on deep litter system from July to October for 20 weeks. Four different flocks (lines) of New Hampshire viz. NH-Khajura, $\mathrm{NH}$-Parwanipur, NH-Khumaltar and NH-Pokhara and three different flocks (lines) of Giriraja viz. GR-Pakhribas, GR-Khumaltar and GR-Tarhara were maintained for the experiment.

\section{Laboratory analyses}

The 40 to 60 weeks eggs were collected and studied for hatchability, fertility and external and internal egg parameters using the standard protocol. Fertility was taken as the percentage of eggs that were fertile out of the eggs set. Hatchability was taken as total number of chicks hatched. Egg, yolk and albumen weight was measured by using electronic balance. Egg width and length were measured using a vernier caliper. Shell thickness was measured using micrometer screw gauge. Yolk and albumen height was taken by using a tripod spheremeter. Yolk width was measured by using a ruler. Yolk index was measured as the ratio of yolk height to yolk diameter, multiplying with 100 . Albumen width was measured using a ruler. Albumen index was measured as the ratio of Albumen height to albumen width, multiplying with 100 .

\section{Statistical Analysis}

Data collected were subjected to one way analysis of variance, using the General Linear Models (GLM) employing appropriate software. Significant differences between mean values were compared at $5 \%$ and $1 \%$ significance level.

The statistical model used was:

$$
\text { Yijk }=\mu+a i+b j+e i j k
$$

Where:

Yijk = performance of the jth individual of the ith genotype and line,

$\mu=$ general mean of the parameter, $a_{i}=$ fixed effect of the genotype $i(i=1-2)$,

$b j=$ fixed effect of theline $(i=1-7)$,

eij $=$ residual error.

\section{Results and Discussion}

\section{Fertility}

The fertility data of two different genotypes of chicken (NH and GR) and their different lines are shown in Table 1 . The results as shown in Table 1 reveals that the fertility between the two different genotypes had significant difference $(P<0.01)$ with the value $(95 \pm 0.26)$ and $(94 \pm 0.39)$ in $\mathrm{NH}$ and GR breed respectively. Islam et al., (1947) reported that higher fertility has been recorded for light breed when compared with heavy breed which is as per the finding of this study as fertility of $\mathrm{NH}$-breed is higher than that of GR. Sapp et al., (2004) revealed breeds, strains, family as well as individuals within a family differ with respect to fertility as there is differences between different lines and genotype in the study. Similarly, line comparison between the different breeds revealed significant difference $(P<0.01)$. According to the tabular observation, among the four different lines of New Hampshire, the fertility of New- Hampshire- Khajura was greatest with (98 \pm 0.19$)$, while New- Hampshire, Khumaltar was lowest with $(94 \pm 0.5)$. Similarly, among the three different lines of Giriraja, the fertility of Giriraja, Tarhara was greatest with $(97 \pm 0.51)$, while Giriraja, Khumaltar was lowest with $(91 \pm 0.51)$. In a study conducted by Kirk et al. (1980) with broiler breeders revealed that fertility and hatchability decreased with age. Fertility affects the number of progeny that can be obtained from a given number of eggs and is determined by candling. The significantly lower mean fertility $(P<0.05)$ recorded pure breed could probably be attributed to the effect of the high ambient temperature prevailing in the experimental area but needs further investigation. King'Ori et al., (2010) stated that chickens struggle at high temperature, because of their feather cover and this hinders internal heat dissipation leading to elevated body temperature and subsequently a decrease in feed intake and thus nutrient intake. Hence, eggs produced by the hens may not have contained enough of all the essential nutrients necessary for embryonic development to take place. Further, fertility in this study is considered as only quality of female but this varies upon male ability to mate successfully, quantity and quality of semen deposited (Brillard, 2003); thus this might be also one of the reason for variations between different lines and genotype. 
Egg quality of New Hampshire and Giriraja chicken

Table 1: Fertility of New Hampshire (NH) and Giriraja (GR) Chicken and their different lines

\begin{tabular}{|c|c|c|c|}
\hline Genotypes and Lines & No of observation & $\begin{array}{c}\text { Fertility \% } \\
(\text { LS Mean } \pm \text { SEM) }\end{array}$ & Level of significance \\
\hline Overall mean & 138 & $95 \pm 0.26$ & \\
\hline Genotypes & & & $* *$ \\
\hline New Hampshire & 78 & $95 \pm 0.34$ & \\
\hline Giriraja & 60 & $94 \pm 0.39$ & \\
\hline CV & & 3.20 & \\
\hline $\mathrm{R}^{2}$ & & 0.062 & \\
\hline Lines & & & $* * *$ \\
\hline $\mathrm{NH}-$ Khajura & 20 & $98 \pm 0.19$ & \\
\hline NH- Parwanipur & 20 & $96 \pm 0.51$ & \\
\hline $\mathrm{NH}-$ Khumaltar & 20 & $93 \pm 0.51$ & \\
\hline NH- Pokhara & 20 & $94 \pm 0.51$ & \\
\hline GR- Pakhribas & 20 & $93 \pm 0.51$ & \\
\hline GR- Khumaltar & 20 & $91 \pm 0.51$ & \\
\hline GR- Tarahara & 20 & $96 \pm 0.51$ & \\
\hline CV & & 5.06 & \\
\hline$R^{2}$ & & 0.473 & \\
\hline
\end{tabular}

Note: NH, New Hampshire; GR, Giriraja; LS, Least Square; SEM, Standard Error of Mean. ** Significant at $0.5 \%$ level; *** Significant at $0.1 \%$ level.

\section{Hatchability}

The hatchability traits of two different genotypes viz New Hampshire and Giriraja obtained in this study are shown in Table 2 . The results obtained above reveals that the hatchability \% between the two different genotypes did not differ. But line comparison between the different breeds revealed significant difference $(P<0.01)$.

Table 2: Hatchability of different lines of New Hampshire (NH) and Giriraja (GR) chicken

\begin{tabular}{lccc}
\hline Genotypes and Lines & No of observation & $\begin{array}{c}\text { Hatchability \% } \\
\text { (LS Mean } \pm \text { SEM) }\end{array}$ & Level of significance \\
\hline Overall mean & 138 & $78 \pm 0.38$ & NS \\
Genotypes & 78 & $79 \pm 0.50$ & $* 27 \pm 0.57$ \\
NH & 60 & 5.71 \\
GR & & 0.021 & \\
CV & & \\
R & & $78 \pm 0.33$ \\
Lines & 20 & $82 \pm 0.93$ \\
NH- Khajura & 20 & $79 \pm 0.88$ \\
NH- Parwanipur & 20 & $76 \pm 0.88$ \\
NH- Khumaltar & 20 & $78 \pm 0.88$ \\
NH- Pokhara & 20 & $76 \pm 0.88$ \\
GR- Pakhribas & 20 & $75 \pm 0.88$ \\
GR- Khumaltar & 20 & 5.06 \\
GR- Tarahara & & 0.26 \\
CV & & \\
R & & \\
\hline
\end{tabular}

Note: NH, New Hampshire; GR, Giriraja; LS, Least Square; SEM, Standard Error of Mean. ** Significant at $0.5 \%$ level; *** Significant at $0.1 \%$ level. 
Baskota et al. (2020) Bang. J. Anim. Sci. 49 (2):108-118

Table 3: Egg weight of New Hampshire and Giriraja and their different lines

\begin{tabular}{lccc}
\hline Genotypes and Lines & No of observation & $\begin{array}{c}\text { Egg Weight (g) } \\
\text { (LS Mean } \pm \text { SEM) }\end{array}$ & $\begin{array}{c}\text { Level of } \\
\text { significance }\end{array}$ \\
\hline Overall mean & 138 & $49 \pm 0.19$ & NS \\
Genotypes & 78 & $49 \pm 0.26$ & \\
New Hampshire (NH) & 60 & $49 \pm 0.29$ & $* * *$ \\
Giriraja (GR) & & 4.71 & \\
CV & & 0.008 & \\
R & 20 & $49 \pm 0.35$ & \\
Lines & 20 & $51 \pm 0.33$ & \\
NH- Khajura & 20 & $51 \pm 0.33$ & \\
NH- Parwanipur & 20 & $47 \pm 0.33$ & \\
NH- Khumaltar & 20 & $49 \pm 0.33$ & \\
NH- Pokhara & 20 & $51 \pm 0.33$ & \\
GR- Pakhribas & 20 & $47 \pm 0.33$ & \\
GR- Khumaltar & & 3.08 \\
GR- Tarahara & & 0.59 & \\
\hline CV & & & \\
R & & & \\
\hline
\end{tabular}

Note: NH, New Hampshire; GR, Giriraja; LS, Least Square; SEM, Standard Error of Mean. ** Significant at $0.5 \%$ level; *** Significant at $0.1 \%$ level.

Table 4: Egg length of New Hampshire and Giriraja and their different lines

\begin{tabular}{lccc}
\hline Genotypes and Lines & No of observation & $\begin{array}{c}\text { Egg Length (mm) } \\
\text { (LS Mean } \pm \text { SEM) }\end{array}$ & $\begin{array}{c}\text { Level of } \\
\text { significance }\end{array}$ \\
\hline Overall mean & 138 & $45 \pm 0.25$ & $* * *$ \\
Genotypes & 78 & $50 \pm 0.32$ & $* * *$ \\
New Hampshire (NH) & 60 & $40 \pm 0.31$ \\
Giriraja (GR) & & 6.35 & \\
CV & & 0.76 & \\
R $^{2}$ & 20 & $54 \pm 0.39$ \\
Lines & 20 & $52 \pm 0.37$ & \\
NH- Khajura & 20 & $49 \pm 0.37$ & \\
NH- Parwanipur & 20 & $47 \pm 0.37$ \\
NH- Khumaltar & 20 & $42 \pm 0.37$ \\
NH- Pokhara & 20 & $40 \pm 0.30$ \\
GR- Pakhribas & 20 & $38 \pm 0.30$ & \\
GR- Khumaltar & & 3.61 \\
GR- Tarahara & & 0.92 \\
\hline CV & & & \\
R & & & \\
\hline
\end{tabular}

Note: NH, New Hampshire; GR, Giriraja; LS, Least Square; SEM, Standard Error of Mean. ** Significant at $0.5 \%$ level; *** Significant at $0.1 \%$ level.

Among the four different lines of New Hampshire, the hatchability of New- Hampshire, Parwanipur was greatest (1.90 \pm 0.93$)$, while New- Hampshire, Pokhara was lowest $(76.03 \pm 0.88)$. Similarly, among the three different lines of Giriraja, the hatchability \% of Giriraja, Pakhribas was greatest (78 \pm 0.88$)$, while Giriraja, Tarhara was lowest with $(75 \pm 0.88)$. Results indicated significant $(P<0.05)$ effect of genotype on hatchability of eggs. Percentage hatchability was $(79 \pm 0.50)$ and (77 \pm 0.57$)$, respectively. There was no significant variation in terms of hatchability. Tamang et al (2011) claimed that the hatchability percent was observed high in the breed of Cobb $500 \times$ New Hampshire and Giriraja x Black Australorp, i.e. $96.43 \%$ and $95.45 \%$ respectively. The result does not resemble the findings. This might be due difference in pure breed and crossings. Tom have (1958) reported that greater variation in fertile egg percentage in early production cycle than later. The findings of Njenga (2005) stated that the hatchability percentages of Giriraja and New Hampshire genotypes were $74.40 \%$ and $75.10 \%$ respectively which is similar to the results of research findings. Hatchability is the percentage of fertile eggs that hatched or percentage of eggs that hatched from all the eggs incubated over a period of 21 days. Further Sapp et al., (2004) indicated nongenetic factors have a higher influence on these traits. There are many factors contributing to the failure of a fertile egg to hatch and these include lethal genes, insufficient nutrients in the egg, bad hatchery practices and exposure to conditions that do not meet the needs of the developing embryo (Peters, 2005: Parmar et al., 2006: Permsak, 1996: Rogue, 1994 and Bhur, 1995). 
Egg quality of New Hampshire and Giriraja chicken

Table 5: Egg diameter of New Hampshire and Giriraja and their different lines

\begin{tabular}{|c|c|c|c|}
\hline Genotypes and Lines & $\begin{array}{c}\text { No of } \\
\text { observation }\end{array}$ & $\begin{array}{c}\text { Egg Diameter } \\
(\text { LS Mean } \pm \text { SEM) }\end{array}$ & $\begin{array}{c}\text { Level of } \\
\text { significance }\end{array}$ \\
\hline Overall mean & 138 & $41 \pm 0.17$ & \\
\hline Genotypes & & & $* * *$ \\
\hline New Hampshire $(\mathrm{NH})$ & 78 & $41 \pm 0.32$ & \\
\hline Giriraja (GR) & 60 & $40 \pm 0.26$ & \\
\hline $\mathrm{CV}$ & & 4.96 & \\
\hline $\mathrm{R}^{2}$ & & 0.10 & \\
\hline Lines & & & $* * *$ \\
\hline NH- Khajura & 20 & $42 \pm 0.31$ & \\
\hline NH- Parwanipur & 20 & $42 \pm 0.30$ & \\
\hline $\mathrm{NH}-$ Khumaltar & 20 & $39 \pm 0.30$ & \\
\hline NH- Pokhara & 20 & $42 \pm 0.30$ & \\
\hline GR- Pakhribas & 20 & $42 \pm 0.30$ & \\
\hline GR- Khumaltar & 20 & $39 \pm 0.30$ & \\
\hline GR- Tarahara & 20 & $37 \pm 0.30$ & \\
\hline $\mathrm{CV}$ & & 4.28 & \\
\hline$R^{2}$ & & 0.54 & \\
\hline
\end{tabular}

Note: NH, New Hampshire; GR, Giriraja; LS, Least Square; SEM, Standard Error of Mean. ** Significant at $0.5 \%$ level; $* * *$ Significant at $0.1 \%$ level.

\section{Egg weight}

The results of egg weight of two genotypes and their lines are shown in Table 3 . The results obtained above reveals that the egg weight among the two different genotypes revealed no significant difference. But in contrast, line comparison between the different breeds revealed significant difference $(<0.01)$. According to the tabular observation, among the four different lines of New Hampshire, the egg weight of the $\mathrm{NH}-$ Parwanipur and $\mathrm{NH}-$ Khumaltar, were almost same i.e. $(51 \pm 0.33 \mathrm{~g})$ and $(51 \pm 0.33 \mathrm{~g})$. The highest weight of egg was recorded in these two lines whereas the lowest weight was recorded in $\mathrm{NH}$ - Pokhara i.e. $(47 \pm 0.33 \mathrm{~g})$. Similarly, among the three different lines of Giriraja, the highest weight of egg was recorded from GR-Khumaltar, and lowest egg weight was recorded from GR-

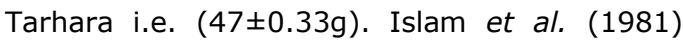
crossbred to upgrade the laying performance of indigenous birds by crossing with exotic breeds of White Leg Horn, New Hampshire and White Cornish and reported that there was about $70 \%$ improvement in egg size in graded chickens as compared to egg size of indigenous chicken. The average egg weights were $57 \mathrm{~g}$ for WL $X$ indigenous, $53 \mathrm{~g}$ for $\mathrm{NH} X$ indigenous and $50 \mathrm{~g}$ for WC $X$ indigenous crosses. The base for Dayanand's study is crossing but this particular study is based on selection which might be claimed as cause of difference.

Additionally, Monira et al., (2003) reported that the egg weight in Giriraja was $64 \mathrm{~g}$ and in New Hampshire was $53 \mathrm{~g}$. There is a great variation but the reason could not be explored yet. It can be stated as different factors such as nutrition, breeding, feeding and other non-genetic factors.

\section{Egg Length, Diameter and Shape Index}

The egg length $(\mathrm{mm})$ of the two different genotypes viz New Hampshire and Giriraja of different lines obtained have been given in Table 4. The results obtained above reveals that the egg length among the two different genotypes revealed significant difference $(<0.01)$ with the value $(50 \pm 0.32 \mathrm{~mm})$ for $\mathrm{NH}$ and $(40 \pm 0.31 \mathrm{~mm})$ for Giriraja. Similarly, line comparison between the different breeds revealed significant difference $(<0.01)$. According to the tabular observation, among the four different lines of New Hampshire, the egg length of $\mathrm{NH}-$ Khajura was highest with the value of $(54 \pm 0.39 \mathrm{~mm})$. The lowest egg length was recorded in $\mathrm{NH}$ - Pokhara with the value of (47 \pm 0.37$)$. Similarly, among the three different lines of Giriraja, the egg length of GR- Tarhara and GR-Pakhribas was recorded highest i.e. $(42 \pm 0.37 \mathrm{~mm})$ and lowest egg length was recorded from GR- Tarhara (38 $\pm 0.30 \mathrm{~mm}$ ). 
Baskota et al. (2020) Bang. J. Anim. Sci. 49 (2):108-118

Table 6: Shape Index of New Hampshire and Girirajaand their different lines

\begin{tabular}{|c|c|c|c|}
\hline Genotypes and Lines & No of observation & $\begin{array}{c}\text { Shape Index } \\
(\text { LS Mean } \pm \text { SEM) }\end{array}$ & $\begin{array}{c}\text { Level of } \\
\text { significance }\end{array}$ \\
\hline Overall mean & 138 & $81 \pm 0.41$ & \\
\hline Genotypes & & & $* * *$ \\
\hline New Hampshire (NH) & 78 & $82 \pm 0.54$ & \\
\hline Giriraja (GR) & 60 & $79 \pm 0.06$ & \\
\hline CV & & 5.98 & \\
\hline $\mathrm{R}^{2}$ & & 0.075 & \\
\hline Lines & & & $* * *$ \\
\hline $\mathrm{NH}-$ Khajura & 20 & $78 \pm 0.81$ & \\
\hline $\mathrm{NH}-$ Parwanipur & 20 & $79 \pm 0.77$ & \\
\hline $\mathrm{NH}-$ Khumaltar & 20 & $80 \pm 0.77$ & \\
\hline NH- Pokhara & 20 & $90 \pm 0.77$ & \\
\hline GR-Pakhribas & 20 & $79 \pm 0.77$ & \\
\hline GR- Khumaltar & 20 & $80 \pm 0.77$ & \\
\hline GR- Tarahara & 20 & $79 \pm 0.77$ & \\
\hline $\mathrm{CV}$ & & 3.32 & \\
\hline $\mathrm{R}^{2}$ & & 0.61 & \\
\hline
\end{tabular}

Table 7: Shell thickness of New Hampshire and Giriraja and their different lines

\begin{tabular}{lccc}
\hline Genotypes and Lines & No of observation & $\begin{array}{c}\text { Shell thickness }(\mathbf{m m}) \\
\text { (LS Mean } \pm \text { SEM) }\end{array}$ & $\begin{array}{c}\text { Level of } \\
\text { significance }\end{array}$ \\
\hline Overall mean & 138 & $0.28 \pm 0.06$ & $* * *$ \\
Genotypes & 78 & $0.28 \pm 0.08$ \\
New Hampshire (NH) & 60 & $0.29 \pm 0.09$ \\
Giriraja (GR) & & 2.71 \\
CV & & 0.21 \\
R & 20 & \\
Lines & 20 & $0.27 \pm 0.01$ \\
NH- Khajura & 20 & $0.28 \pm 0.01$ \\
NH- Parwanipur & 20 & $0.28 \pm 0.01$ \\
NH- Khumaltar & 20 & $0.27 \pm 0.01$ \\
NH- Pokhara & 20 & $0.28 \pm 0.01$ \\
GR- Pakhribas & 20 & $0.29 \pm 0.01$ \\
GR- Khumaltar & & $0.29 \pm 0.15$ \\
GR- Tarahara & & 2.47 \\
\hline CV & & 0.36 \\
R & & \\
\hline
\end{tabular}

Note: NH, New Hampshire; GR, Giriraja; LS, Least Square; SEM, Standard Error of Mean. ** Significant at $0.5 \%$ level; *** Significant at $0.1 \%$ level.

\section{Egg Diameter}

The egg diameter $(\mathrm{mm})$ included the two different genotypes viz. New Hampshire and Giriraja with different lines revealed the following results. Results obtained above reveals that the egg diameter among the two different genotypes differed significantly $(<0.01)$. Similarly, line comparison between the different breeds revealed significant difference $(<0.01)$ too. According to the tabular observation, among the four different lines of
New Hampshire, the egg length of $\mathrm{NH}-$ Khajura was highest $(42 \pm 0.31 \mathrm{~mm})$. The lowest egg length value was recorded in $\mathrm{NH}-$ Pokhara $(39 \pm 0.30 \mathrm{~mm})$. Similarly, among the three different lines of Giriraja, the highest egg diameter was recorded from GR- Pakhribas $(42 \pm 0.37 \mathrm{~mm})$ and lowest for the same was recorded from GR- Tarhara (38 $\pm 0.30 \mathrm{~mm})$. There is a great variation with the findings. The reason could not be explored, yet it can be stated as different factors such as nutrition, breeding (Parmar et al.,2006). 
Egg quality of New Hampshire and Giriraja chicken

Table 8: Yolk Weight of New Hampshire and Giriraja and their different lines

\begin{tabular}{|c|c|c|c|}
\hline Genotypes and Lines & No of observation & $\begin{array}{l}\text { Yolk Weight (g) } \\
(\text { LS Mean } \pm \text { SEM) }\end{array}$ & $\begin{array}{c}\text { Level of } \\
\text { significance }\end{array}$ \\
\hline Overall mean & 138 & $16 \pm 0.59$ & \\
\hline Genotypes & & & NS \\
\hline New Hampshire $(\mathrm{NH})$ & 78 & $15 \pm 0.77$ & \\
\hline Giriraja (GR) & 60 & $16 \pm 0.88$ & \\
\hline CV & & 4.40 & \\
\hline $\mathrm{R}^{2}$ & & 0.003 & \\
\hline Lines & & & $* * *$ \\
\hline NH- Khajura & 20 & $15 \pm 0.14$ & \\
\hline NH- Parwanipur & 20 & $16 \pm 0.13$ & \\
\hline $\mathrm{NH}-\mathrm{Khumaltar}$ & 20 & $16 \pm 0.13$ & \\
\hline NH- Pokhara & 20 & $15 \pm 0.13$ & \\
\hline GR- Pakhribas & 20 & $16 \pm 0.13$ & \\
\hline GR- Khumaltar & 20 & $16 \pm 0.13$ & \\
\hline GR- Tarahara & 20 & $15 \pm 0.13$ & \\
\hline $\begin{array}{l}\mathrm{CV} \\
\mathrm{R}^{2}\end{array}$ & & & \\
\hline
\end{tabular}

Note: NH, New Hampshire; GR, Giriraja; LS, Least Square; SEM, Standard Error of Mean. ** Significant at $0.5 \%$ level; *** Significant at $0.1 \%$ level.

Table 9: Yolk Index of New Hampshire and Giriraja and their different lines

\begin{tabular}{|c|c|c|c|}
\hline Genotypes and Lines & No of observation & $\begin{array}{c}\text { Yolk Index } \\
(\text { LS Mean } \pm \text { SEM) }\end{array}$ & Level of significance \\
\hline Overall mean & 138 & $0.34 \pm 0.04$ & \\
\hline Genotypes & & & NS \\
\hline New Hampshire $(\mathrm{NH})$ & 78 & $0.34 \pm 0.04$ & \\
\hline Giriraja (GR) & 60 & $0.34 \pm 0.06$ & \\
\hline CV & & 14.54 & \\
\hline $\mathrm{R}^{2}$ & & 0.000 & \\
\hline Lines & & & NS \\
\hline $\mathrm{NH}-$ Khajura & 20 & $0.34 \pm 0.04$ & \\
\hline NH- Parwanipur & 20 & $0.33 \pm 0.01$ & \\
\hline $\mathrm{NH}-$ Khumaltar & 20 & $0.33 \pm 0.01$ & \\
\hline $\mathrm{NH}$ - Pokhara & 20 & $0.33 \pm 0.01$ & \\
\hline GR- Pakhribas & 20 & $0.35 \pm 0.01$ & \\
\hline GR- Khumaltar & 20 & $0.35 \pm 0.01$ & \\
\hline GR- Tarahara & 20 & $0.34 \pm 0.01$ & \\
\hline CV & & 14.61 & \\
\hline$R^{2}$ & & 0.02 & \\
\hline
\end{tabular}

Note: NH, New Hampshire; GR, Giriraja; LS, Least Square; SEM, Standard Error of Mean. ** Significant at $0.5 \%$ level; *** Significant at $0.1 \%$ level.

\section{Shape Index}

The shape index of the two different genotypes viz. New Hampshire and Giriraja with different lines obtained revealed the following results which have been given through the Table 6 . The results obtained above reveals that the shape index among the two different genotypes revealed significant difference $(P<0.01)$ $(82 \pm 0.54)$ for $\mathrm{NH}$ and $(79 \pm 0.06)$ for Giriraja. Similarly, line comparison between the different breeds revealed significant difference $(<0.01)$. According to the tabular observation, among the four different lines of New Hampshire, the shape index of $\mathrm{NH}^{-}$Pokhara was the highest
$(89 \pm 0.77 \mathrm{~mm})$. The lowest shape index was recorded lowest in $\mathrm{NH}-$ Khajura (78 \pm 0.81$)$. Similarly, among the three different lines of Giriraja, the shape index of GR- Khumaltar recorded highest $(79 \pm 0.77)$ and lowest was recorded from GR- Tarhara (78 \pm 0.77$)$. Shape index of 75 was reported by Reddy (2004) in White Leghorn layers. The finding of the result reveals similar (78 to 89 ). The exact reason could not be explored; however, genetic factors might be responsible. Similarly, Parmar et al. (2003) conducted an experiment and found that the shape index of Kadaknath breed was 73.98. This varies with the findings, and the reason could be 
the difference of breed. Monira et al. (2003) stated that shape index of Giriraja and New Hampshire at 40 weeks of age to significantly higher (78.88) and (78.67) respectively. This resembles the findings, meaning the eggs of different breeds and lines possess standard shape and size.

\section{Shell Thickness}

The shell thickness of the two different genotypes viz New Hampshire and Giriraja with different lines obtained revealed the following results which have been given through the Table 7. The results obtained above reveals that the shell thickness among the two different genotypes revealed significant difference $(P<0.01)$ $(0.28 \pm 0.08 \mathrm{~mm})$ for $\mathrm{NH}$ and $(0.29 \pm 0.09 \mathrm{~mm})$ for Giriraja. Similarly, line comparison between the different breeds revealed significant difference $(P<0.01)$ too. According to the tabular observation, among the four different lines of New Hampshire, the shell thickness of $\mathrm{NH}$ Khumaltar was highest with $(0.28 \pm 0.01 \mathrm{~mm})$. The lowest shell thickness was recorded in $\mathrm{NH}$ Parwanipur $(0.27 \pm 0.01 \mathrm{~mm})$. Similarly, among the three different lines of Giriraja, the shell thickness of GR- Tarhara and GR-Khumaltar was recorded highest $(0.29 \pm 0.15 \mathrm{~mm})$ and lowest shell thickness was recorded from GR- Pakhribas $(0.28 \pm 0.01 \mathrm{~mm})$. Padhi et al. (1998) reported that the shell thickness of $0.29 \mathrm{~mm}$ in New Hampshire and $0.31 \mathrm{~mm}$ in Giriraja respectively. This result resembles the findings of the research result i.e. shell thickness ranged between 0.27 -
$0.29 \mathrm{~mm}$. Similarly, Niranjan et al. (2008) reported that the shell thickness of Giriraja and New Hampshire were $0.32 \mathrm{~mm}$. The result varies with the findings; however, the actual cause of such variation could be understood but the cause for such variation might be due to physical make up and chemical composition of its constituent parts.

\section{Yolk Weight}

The Yolk Weight of the two different Genotypes viz. New Hampshire and Giriraja obtained revealed the following results which have been given through the Table 8 . The results obtained above reveals that the yolk weight among the two different genotypes revealed no significant difference. But in contrast, line comparison between the different breeds revealed significant difference $(P<0.01)$. According to the tabular observation, among the four different lines of New Hampshire, the yolk weight of the $\mathrm{NH}$ Parwanipur and $\mathrm{NH}$ - Khumaltar were same i.e. $(16 \pm 0.13 \mathrm{~g})$. The highest weight of yolk was recorded in these two lines whereas the lowest weight was recorded in $\mathrm{NH}$ - Pokhara i.e. $(15 \pm 0.13 \mathrm{~g})$. Similarly, among the three different lines of Giriraja, the highest weight of egg was recorded from Giriraja, Khumaltar i.e. $(16 \pm 0.13 \mathrm{~g})$ and lowest yolk weight was recorded from GR- Tarhara i.e. $(15 \pm 0.13 \mathrm{~g})$. The reason behind such variation could not be explored, however, the probable reason for such outcome might be due to influence by both genetic and non-genetic factors (Parmar et al., 2006).

Table 10: Albumin Weight of New Hampshire and Giriraja and their different lines

\begin{tabular}{lcrc}
\hline Genotypes and Lines & $\begin{array}{c}\text { No of } \\
\text { observation }\end{array}$ & $\begin{array}{c}\text { Albumin Weight(g) } \\
\text { (LS Mean } \pm \text { SEM) }\end{array}$ & $\begin{array}{c}\text { Level of } \\
\text { significance }\end{array}$ \\
\hline Overall mean & 138 & $25 \pm 0.19$ & NS \\
Genotypes & 78 & $25 \pm 0.54$ & $* * *$ \\
New Hampshire (NH) & 60 & $25 \pm 0.77$ & 8.99 \\
Giriraja (GR) & & 0.001 & \\
CV & & & \\
R $^{2}$ & 20 & $23 \pm 0.43$ & $24 \pm 0.41$ \\
Lines & 20 & $25 \pm 0.41$ & $27 \pm 0.41$ \\
NH- Khajura & 20 & $24 \pm 0.41$ \\
NH- Parwanipur & 20 & $25 \pm 0.41$ \\
NH- Khumaltar & 20 & $26 \pm 0.41$ \\
NH- Pokhara & 20 & 7.43 \\
GR- Pakhribas & 20 & 0.34 \\
GR- Khumaltar & & \\
GR- Tarahara & & & \\
\hline CV & & & \\
R & & & \\
\hline
\end{tabular}

Note: NH, New Hampshire; GR, Giriraja; LS, Least Square; SEM, Standard Error of Mean. ** Significant at $0.5 \%$ level; *** Significant at $0.1 \%$ level. 
Egg quality of New Hampshire and Giriraja chicken

Table 11: Albumin Index of New Hampshire and Giriraja and their different lines

\begin{tabular}{lccc}
\hline Genotypes and Lines & $\begin{array}{c}\text { No of } \\
\text { observation }\end{array}$ & $\begin{array}{c}\text { Albumen Index } \\
\text { (LS Mean } \pm \text { SEM) }\end{array}$ & $\begin{array}{c}\text { Level of } \\
\text { significance }\end{array}$ \\
\hline Overall mean & 138 & $0.16 \pm 0.04$ & NS \\
Genotypes & 78 & $0.14 \pm 0.04$ \\
New Hampshire (NH) & 60 & $0.14 \pm 0.06$ \\
Giriraja (GR) & & \\
CV & & \\
R $^{2}$ & 20 & \\
Lines & 20 & $0.14 \pm 0.04$ \\
NH- Khajura & 20 & $0.13 \pm 0.01$ \\
NH- Parwanipur & 20 & $0.13 \pm 0.01$ \\
NH- Khumaltar & 20 & $0.13 \pm 0.01$ \\
NH- Pokhara & 20 & $0.15 \pm 0.01$ \\
GR- Pakhribas & 20 & $0.15 \pm 0.01$ \\
GR- Khumaltar & & $0.14 \pm 0.01$ \\
GR- Tarahara & & 14.61 \\
\hline CV & & 0.02 \\
R & & $* *$ \\
\hline
\end{tabular}

Note: NH, New Hampshire; GR, Giriraja; LS, Least Square; SEM, Standard Error of Mean. ** Significant at $0.5 \%$ level; *** Significant at $0.1 \%$ level.

\section{Yolk Index}

The yolk index of the two different genotypes viz. New Hampshire and Giriraja obtained revealed the following results which have been given through the Table 9. The results obtained from the table reveals that the Yolk Index among the two different genotypes revealed no significant difference with same value $(0.34 \pm 0.04)$. Similarly, line comparison between the different breeds revealed no significant difference too. According to the tabular observation, among the four different lines of New Hampshire, the yolk index of the $\mathrm{NH}-$ Pokhara, Parwanipur and Khumaltar recorded the same $(0.33 \pm 0.01)$. The highest yolk index was recorded from $\mathrm{NH}$ Khajura (0.34 \pm 0.04$)$ and lowest yolk index was recorded in $\mathrm{NH}-$ Parwanipur, Pokhara and Khumaltar $(0.33 \pm 0.01)$. Similarly, among the three different lines of Giriraja, the highest yolk index was recorded from Giriraja, Pakhribas and GR- Khumaltar with the same value $(0.35 \pm 0.01)$ and lowest egg yolk index was recorded from GRTarhara (0.34 \pm 0.0$)$. No significant difference was observed.The study made by Sohail et al., (2013) reported that non-significant differences $(P>$ 0.05 ) were observed in the yolk index (0.380.42 ) of eggs from Giriraja hens in the 1st, 2nd and 3rd production cycles of Peshawari Aseel chickens which reassembles the findings.

\section{Albumen Weight}

The albumin weight of the two different genotypes viz. New Hampshire and Giriraja with different lines obtained revealed the following results which have been given through the Table 10 enlisted above. The results obtained above reveals that the albumin weight among the two different genotypes revealed no significant difference with same value $(25 \pm 0.54 \mathrm{~g})$. But in contrast, line comparison between the different breeds revealed significant difference.According to the tabular observation, among the four different lines of New Hampshire, the albumin weight of the $\mathrm{NH}-$ Pokhara was highest $(27 \pm 0.41 \mathrm{~g})$. The lowest albumin weight was recorded in $\mathrm{NH}$ - Khajura $(23 \pm 0.43 \mathrm{~g})$. Similarly, among the three different lines of Giriraja, the highest albumin weight was recorded from Giriraja, Tarhara with the value $(26 \pm 0.41 \mathrm{~g})$ and lowest albumin weight was recorded from GRPakhribas $(0.34 \pm 0.0 \mathrm{~g})$. Significant difference was observed $(P<0.01)$. The variation could be due to environmental and non-genetic factors responsible for such outcome which reassembles the findings of Baishya et al., (2008) as experiment conducted by Baishya et al., (2008) to determine the certain qualities of different sources of chicken eggs namely indigenous chicken, farm chicken, market chicken and Giriraja chicken and found variation in albumen qualities. 


\section{Albumen Index}

The Albumin Index of the two different genotypes viz. New Hampshire and Giriraja with different lines obtained revealed the following results which have been given through the Table 11 .

The results obtained from the table reveals that the Albumen Index among the two different genotypes revealed no significant difference $(0.14 \pm 0.04)$. But, in contrast line comparison between the different breeds revealed significant difference $(P<0.01)$. According to the tabular observation, among the four different lines of New Hampshire, the ALI of $\mathrm{NH}-$ Khajura was highest $(0.14 \pm 0.04)$. The lowest albumin width was recorded in $\mathrm{NH}-$ Parwanipur, Khumaltar and Pokara (0.13 \pm 0.01$)$. Similarly, among the three different lines of Giriraja, the albumin index of GR- Pakhribas and GR-Khumaltar was recorded highest $(0.15 \pm 0.01)$ and lowest albumin index was recorded from GR- Tarhara $(0.14 \pm 0.01)$. Both genetic and non-genetic reason have the influence for such an outcome (Parmar et al., 2006). Hasan et al., (2009) reported that the albumen index of New Hamshire chicken was 0.16 and this reassembles finding of the study.

\section{Conclusion}

Based on the results of the present study, $\mathrm{NH}$ chicken both in terms of genotype and lines was superior to $G R$ in terms of egg production. Among the different lines $\mathrm{NH}$-Khajura performed better for the same than other lines. Therefore it is suggested that the line of $\mathrm{NH}-\mathrm{Khajura}$ can be used for parent stock or can be used in backyard poultry for egg production.

\section{Acknowledgement}

I am grateful to all the staffs of Swine and avian Research Program, Khumaltar. Kathmundu, Nepal.

\section{Conflict of interest}

There is no conflict of interest among the authors.

\section{References}

Baishya D, KK Dutta, JD Mahanta and RN Borpujari (2008). Studies on certain qualities of different sources of chicken eggs. Tamil Nadu Journal of Veterinary and Animal Sciences 4(4): 139-141.

Bhurtel R and BKP Shaha (2000). Poultry development in Nepal: constraints and potentialities. Research report. Winrock International 45:51.

Brillard JP (2003) Practical aspects of fertility in poultry. World's Poultry Science Journal 59: 441-446.
Centra Bureau of Statistics (2015). Nepal Commercial poultry survey. Ministry of Agriculture \& $\mathrm{Co}$ operatives, Nepal. pp.2-5

FAO (2014). Poultry sector in Nepal. Animal Production and Health Livestock Country Reviews 59:29-44.

Hasan A and AA Okur (2009). Effect of storage time, temperature and hen age on egg quality in freerange layer hen. Journal of Animal Sciences and Veterinary Advances 8(10): 1958-1958.

Insko WM, DG Steel and ET Whiteman (1947). Reproductive phenomena in ageing hens. Kentucky Agricultural Experiment Station 498: 1-23.

Islam AB, MM Hoque, and QMF Rahim (1981). Reproductive performance of upgraded indigenous chicken. Poultry Adviser 14: 3-37.

Johanson I and Jan Rendel (1996).Production characters in Poultry. Genetics and Animal Breeding. Department of Animal Breeding, The Agriculture College of Sweden, Uppsala.pp 340360.

Kirk S, GC Emmans, Mcdonald and Arnot (1980). Factors affecting the hatchability of eggs from broiler breeders. British Poultry Science 21: 3753

MoAD (2015). Ministry of Agriculture \& Cooperatives. Statistical Information on Nepalese Agriculture. P18.

Monira K, M Salahuddin and G Miah (2003).Effect of breed and holding period on egg quality characteristics of chicken. Poultry Science 2: 261-263.

Neopane SP and N Gorkhali (2008). Indigenous chicken of Nepal. Animal Breeding Division. Nepal. Animal Science Research Institute (NASRI).Nepal AgricultureResearch Council, Khumaltar, Lalitpur.

Niranjan M, RP Sharma, U Rajkumar, RN Chatterjee, BLN Reddy, and TK Battacharya (2008). Egg quality traits in chicken varieties developed for backyard poultry farming in India. Livestock Research and Rural Development 20: 81-85.

Njenga SK (2005). Productivity and socio-cultural aspects of local poultry phenotypesin coastal Kenya. M.Sc. thesis submitted to the Department of Animal Breeding and Genetics, Danish Institute of Agricultural Science Research Center, Foulumand Network for smallholder Poultry Department. The Royal Veterinary and Agricultural University (KVL), Denmark.

Padhi MK, RB Rai, S Senani and SK Saha (1998). Assessment of egg quality characteristics in White Leghorn layers. Indian Journal of Poultry Science 33: 113-115.

Parajuli DP and UC Thakur (1998). Poultry Development Program. In: J.N.B Shresthat (eds.) Proceeding of the first National Workshop on Animal Genetic Resources, Conservation and genetic improvement of domestic animal in Nepal. Nepal Agriculture Research Council. April11-13,Kathmandu, pp 29-32. 
Egg quality of New Hampshire and Giriraja chicken

Parmar SNS, MS Thakur, SS Tomar and PVA Pillai, (2006). Evaluation of egg quality traits in Livestock Research and Rural Development 18:132137.

Permsak S (1966). Effect of water spraying and eggs turning angle to efficiency of duck hatchability. Proceeding of the 34th Kasetsart University annual conference, Bangkok (Thailand) 517: 2226.

Reddy VB, D Subarayudee and P Varadarajulee (1965).The effect of breed, pre-incubation storage time and egg weight on hatchability of poultry. Animal Breeding Abstracts 34: 268.

Rogue $L$ and MC Soares (1994). Effect of eggshell quality and broiler breeder age on hatchability. Poultry Science 73: 1838-1845.

Sapp RL, R Rekaya, I Misztal and T Wing (2004) Male and female fertility and hatchability in chickens: a longitudinal mixed model approach. Poultry Science 83: 1253-1259 indigenous Kadaknath breed of poultry.

Sohail A, A Muhammad, J Hussain, A Iqbal, M Usman, A Rehman and F Hussnain (2013). Comparative study on productive performance, egg quality, egg geometry and hatching traits of three age groups of indigenous Peshawari Aseel chickens. Scientific Journal of Veterinary Advances 2(2): 21-25.

Tamang DT, MP Sharma and SR Barsila (2015). Performance of meat purpose hybrid chicken under intensive system. Journal of the Institute of Agriculture and Animal Science 34: 187-194.

Weis J (1991). Analysis of fertility, hatchability and egg quality indices in reproduction breeding of guinea fowls. Acta Zootechnic University Agriculture 47: 5-15. 